Article

\title{
The Natural Flavonoid Compound Deguelin Inhibits HCMV Lytic Replication within Fibroblasts
}

\author{
Masatoshi Nukui ${ }^{1}$, Christine M. O'Connor ${ }^{1, *}$ (i) and Eain A. Murphy ${ }^{2, *}$ \\ 1 Genomic Medicine, Lerner Research Institute, Cleveland Clinic, Cleveland, OH 44106, USA; nukuim@ccf.org \\ 2 FORGE Life Science, Pennsylvania Biotechnology Center, Doylestown, PA 18901, USA \\ * Correspondence: oconnoc6@ccf.org (C.M.O.); eain@forgelifescience.com (E.A.M.); \\ Tel.: +1-216-444-0676 (C.M.O.); +1-267-893-6756 (E.A.M.)
}

Received: 17 October 2018; Accepted: 3 November 2018; Published: 7 November 2018

\begin{abstract}
Human cytomegalovirus (HCMV) is a ubiquitous herpesvirus for which there is no vaccine or cure. This viral infection, once acquired, is life-long, residing latently in hematopoietic cells. However, latently infected individuals with weakened immune systems often undergo HCMV reactivation, which can cause serious complications in immunosuppressed and immunocompromised patients. Current anti-viral therapies target late stages of viral replication, and are often met with therapeutic resistance, necessitating the development of novel therapeutics. In this current study, we identified a naturally-occurring flavonoid compound, deguelin, which inhibits HCMV lytic replication. Our findings reveal that nanomolar concentrations of deguelin significantly suppress the production of the infectious virus. Further, we show that deguelin inhibits the lytic cycle during the phase of the replication cycle consistent with early (E) gene and protein expression. Importantly, our data reveal that deguelin inhibits replication of a ganciclovir-resistant strain of HCMV. Together, our findings identify a novel, naturally occurring compound that may prove useful in the treatment of HCMV replication.
\end{abstract}

Keywords: cytomegalovirus; HCMV; deguelin; ganciclovir

\section{Introduction}

Human cytomegalovirus (HCMV) is a betaherpesvirus that infects a majority of the human population. Like all herpesviruses, once an individual is infected, HCMV remains with its host for life, residing in a latent state in cells of the hematopoietic compartment. With the exception of specific subpopulations including fetuses, neonates, stem cell recipients and sero-negative organ transplant recipients, primary HCMV infection poses little threat to otherwise healthy individuals. However, when an infected individual's immune system is severely compromised, HCMV can reactivate from latency, which results in lytic replication, viral spread, and disease that can be fatal.

While there is no vaccine or cure for HCMV, current anti-viral treatments do exist [1]. A majority of the commonly prescribed HCMV antiviral therapies are nucleoside apologues that require active HCMV UL97, a gene that encodes a serine/threonine kinase, pUL97. This HCMV-encoded kinase phosphorylates nucleoside analogs such, as ganciclovir, thereby converting it to a competitive inhibitor of dGTP incorporation into viral DNA by the HCMV encoded DNA polymerase UL54, thus resulting in robust anti-viral activity [2]. Similarly, valganciclovir is also phosphorylated by pUL97, but has increased absorption and bioavailability compared to ganciclovir, due to an L-valyl ester added to the $5^{\prime}$-end of ganciclovir's deoxyribose ring [3]. More recently, maribavir emerged as a promising, new anti-viral, which competes with ATP binding to pUL97, thereby inhibiting its kinase activity [4]. However, these therapies, while potent inhibitors of HCMV, are fraught with problems. Clinicians treating patients suffering from HCMV reactivation are noting a significant increase in drug-resistant 
HCMV strains, due specifically to UL97 mutations. While maribavir seemed promising as an alternative treatment strategy for patients with ganciclovir- or valganciclovir-resistant HCMV, it is now evident that this therapy also leads to drug resistant HCMV.

Drug resistant viral reactivation requires turning to alternative treatments, including foscarnet and cidofovir. Foscarnet, a pyrophosphate analog, is a DNA polymerase inhibitor, but is not activated by pUL97 [5]. Similarly, cidofovir is also a DNA polymerase inhibitor, but unlike the nucleoside analogs ganciclovir or valganciclovir, cidofovir activity does not require phosphorylation by pUL97 [6]. Though these additional drugs seemed promising for treating patients with drug-resistant HCMV, it is now clear that these treatments are also leading to multi-drug resistant strains. Additionally, even in cases where the patient does not become resistant, foscarnet is highly nephrotoxic [7] and cidofovir is associated with severe neutropenia [8]. Recently a viral terminase inhibitor, letermovir, was approved to prophylactically treat hematopoietic cell transplant patients, and recent clinical data suggest that this prophylaxis results in a significant decrease in clinically significant HCMV infection in these patients [9]. However, in vitro testing of the terminase complex suggests that letermovir-resistant strains of HCMV may emerge $[10,11]$. In sum, detrimental side effects of current anti-HCMV treatments, coupled with increasingly hard to manage drug resistant HCMV strains, underscore the need for novel therapeutics that combat HCMV.

In this current study, we show that the naturally occurring compound, deguelin, significantly inhibits HCMV lytic replication. Deguelin [(7aS, BaS)-13, 13a-dihydro-9, 10-dimethoxy-3, 3-dimethyl$3 \mathrm{H}$-bis [1] benzo-prano [3, 4-b: 6', 5'-e] pyran-7 (7aH)-one] is a plant-derived rotenoid compound and is a member of the flavonoid family. This compound has shown anti-cancer activities in pre-clinical trials [12], as well as promoting cell cycle arrest, apoptosis, and inhibiting angiogenesis. Additionally, deguelin blocks phosphoinositides 3-kinase (PI3K)/ Akt activity and binds to the ATP binding domain of Heat Shock Protein $90 \alpha$ (HSP90), all pathways critical for efficient viral infection. Herein, our results reveal that low concentrations of deguelin are effective at inhibiting HCMV by targeting viral early (E) protein expression, thereby reducing the production of infectious virus. These findings suggest that deguelin could prove a novel therapeutic for HCMV lytic infection.

\section{Materials and Methods}

\subsection{Cells, Viruses, and Compounds}

Primary newborn human fibroblasts, NuFF-1 cells (GlobalStem, Rockville, MD, USA), were maintained in Dulbecco's modified Eagle medium (DMEM), supplemented with 10\% fetal bovine serum (FBS), $2 \mathrm{mM}$ L-glutamine, $0.1 \mathrm{mM}$ non-essential amino acids, $10 \mathrm{mM}$ 4-(2-hydroxyethyl)1-piperazineethanesulfonic acid (HEPES), and $100 \mathrm{U} / \mathrm{mL}$ each of penicillin and streptomycin. Cells were grown at $37^{\circ} \mathrm{C}$ in $5 \% \mathrm{CO}_{2}$.

Bacterial artificial chromosome (BAC)-derived TB40/EmCherry [13] and TRgfp [14] are described elsewhere. The recombinant virus TB40/EmCherry-UL99eGFP (UL99eGFP) [15] was generated by tagging the C-terminus of the UL99 open reading frame (ORF) with enhanced green fluorescent protein (eGFP) with the forward (FOR) and reverse (REV) primers listed in Table 1 using standard galK recombineering protocols, described in detail previously (e.g., Refs. $[13,16,17])$. The resultant viral recombinant was sequenced to verify the seamless in-frame insertion of eGFP upstream of the UL99 stop codon. To generate virus stocks, each of the aforementioned viruses were grown as previously described (e.g., Ref. [13]). All viral stocks were titered by 50\% tissue culture infectious dose (TCID 50$)$ assay on NuFF-1 cells. 
Table 1. Primers used in this study.

\begin{tabular}{|c|c|c|}
\hline Primer Use & Sequence & Primer Name \\
\hline galK insertion $^{1}$ & $\begin{array}{c}\text { CAACGTCCACCCACCCCCGGGACAAAAAAGCCCGCCGCCCCC } \\
\text { TTGTCCTTTCCTGTTGACAATTAATCATCGGCA }\end{array}$ & UL99galK $5^{\prime}$ \\
\hline galK insertion $^{1}$ & $\begin{array}{l}\text { GTGTCCCATTCCCGACTCGCGAATCGTACGCGAGACCTGAAA } \\
\text { GTTTATGAGTCAGCACTGTCCTGCTCCTT }\end{array}$ & UL99galK $3^{\prime}$ \\
\hline Reversion primer & $\begin{array}{l}\text { CAACGTCCACCCACCCCCGGGACAAAAAAGCCCGCCGCC } \\
\text { CCCTTGTCCTTTGTGAGCAAGGGCGAGGAGCTGTTCACCG }\end{array}$ & UL99eGFP $5^{\prime}$ \\
\hline Reversion primer & $\begin{array}{c}\text { GTGTCCCATTCCCGACTCGCGAATCGTACGCGAGACCT } \\
\text { GAAAGTTTATGAGTTACTTGTACAGCTCGTCCATGCCGAGAGT }\end{array}$ & UL99eGFP $3^{\prime}$ \\
\hline qPCR/RTqPCR & ATGGTTTTGCAGGCTTTGATG & UL122 FOR \\
\hline qPCR/RTqPCR & ACCTGCCCTTCACGATTCC & UL122 REV \\
\hline RTqPCR & GCCTTCCСТAAGACCACCAAT & UL123 FOR \\
\hline RTqPCR & ATTTTCTGGGCATAAGCCATAATC & UL123 REV \\
\hline RTqPCR & GGC GTG AAA AAC ATG CGT ATC AAC & UL44 FOR \\
\hline RTqPCR & TAC AAC AGC GTG TCG TGC TCC G & UL44 REV \\
\hline RTqPCR & CССТCGGCTTCTCACAACAAT & UL54 FOR \\
\hline RTqPCR & CGAGTTAGTCTTGGCCATGCAT & UL54 REV \\
\hline RTqPCR & CACACAACACCGTCGTCCGATTAC & UL32 FOR \\
\hline RTqPCR & GGTTTCTGGCTCGTGGATGTCG & UL32 REV \\
\hline RTqPCR & GTGTCCCATTCCCGACTCG & UL99 FOR \\
\hline RTqPCR & TTCACAACGTCCACCCACC & UL99 REV \\
\hline RTqPCR & ACССАСТССТССАССТTTGAC & GAPDH $^{2}$ FOR \\
\hline RTqPCR & CTGTTGCTGTAGCCAAATTCGT & GAPDH REV \\
\hline qPCR & ССССТТССАТСАСАТTGСА & MDM $2{ }^{3}$ FOR \\
\hline qPCR & AGTTTGGCTTTCTCAGAGATTTCC & MDM2 REV \\
\hline
\end{tabular}

\footnotetext{
${ }^{1}$ Underlined sequences correspond to the pGalK sequences. ${ }^{2} \mathrm{GAPDH}$, glyceraldehyde 3-phosphate dehydrogenase.

${ }^{3}$ MDM2, mouse double minute 2 homolog.
}

The Spectrum collection of compounds (MicroSource Discovery Systemts, Inc.) was used to treat NuFF-1 cells $(50 \mu \mathrm{M})$ for 2 hours (h) prior to infection with TB40/EmCherry-UL99eGFP at a multiplicity of infection (moi) $=0.01$ for $72 \mathrm{~h}$. Viral replication was measured using mCherry (a marker of infection) and eGFP (a marker of late viral replication) fluorecence, analyzed with an Operetta High Content Imaging System (PerkinElmer, Waltham, MA, USA). Deguelin and ganciclovir were both purchased from Cayman. Deguelin and ganciclovir were reconstituted in dimethyl sulfoxide (DMSO). Deguelin was used at various concentrations, as indicated throughout the text, and ganciclovir was used at $10 \mu \mathrm{M}$.

\subsection{Cytotoxicity and Cytostaticity Assays}

Cytotoxic effects of deguelin were measured by treating confluent NuFF-1 cells with varying concentrations of deguelin for 3 days (d), as indicated. Cell proliferation was measured using the CellTiter 96 AQueous One Solution Cell Proliferation Assay (Promega, Madison, WI, USA), in accordance to the manufacturer's instructions. Absorbance was read at $490 \mathrm{~nm}$ using a Cytation 3 cell imaging plate reader (BioTek, Winooski, VT, USA). Data is plotted as percent inhibition relative to vehicle (DMSO)-treated cells. Cell doubling was assessed by seeding NuFF-1 cells at $25 \%$ confluence and treating with varying concentrations of deguelin, as described in the text. After two cell doublings, cell proliferation was measured using CellTiter 96 AQueous One Solution Cell Proliferation Assay (Promega), as described above. Drug-treated cells were normalized to vehicle (DMSO)-treated cells.

\subsection{Half-Maximal Inhibitory Concentration ( $\left.I C_{50}\right)$ Measurements}

NuFF-1 cells were infected in the presence of varying concentrations of degeulin at either a high multiplicity of infection (moi) of 1.0 or low moi of 0.01 for 7 or $14 \mathrm{~d}$, respectively. Cell-associated DNA was isolated by phenochloroform-isoamyl alcohol precipitation, as previously described [18], for quantitative PCR (qPCR) analyses (described in Section 2.4) and viral supernatants were collected for $\mathrm{TCID}_{50}$ analyses. $\mathrm{IC}_{50}$ was determined using the on-line calculation tool: https:/ /www.aatbio. $\mathrm{com} /$ tools/ic50-calculator/. 


\subsection{Viral RNA, DNA, and Protein Analyses}

NuFF-1 cells were treated with deguelin $(250 \mathrm{nM})$ or vehicle (DMSO) at the indicated concentrations followed by infection with HCMV at multiplicities and durations indicated in the text for subsequent RNA, DNA, or protein analyses. Total RNA was harvested, and viral transcripts were measured by reverse transcriptase quantitative PCR (RTqPCR) using the primers listed in Table 1. Viral transcripts were normalized to cellular GAPDH RNA levels. To assess viral DNA, cell-associated DNA was harvested and assessed by qPCR using primers directed at UL122 (Table 1). All samples were normalized to cellular MDM2 (Table 1). To determine viral protein production, cell lysates were collected as indicated in the text and proteins were separated by SDS-PAGE and then transferred to nitrocellulose using a semi-dry transfer apparatus (Owl). The following antibodies were used: anti-IE2 (clone \#3A9; Ref. [19]) and anti-pp28 (clone \#10B4-29; Ref. [20]), each diluted at 1:1000; anti-pUL44 (Virusys; diluted 1:10,000); and anti-alpha-tubulin (Sigma, St. Louis, MO, USA; diluted 1:5000). In all cases, membranes were incubated with IR Dye 680RD anti-mouse secondary antibody (1:15,000; LI-COR, Lincoln, NE, USA) and scanned using an Odyssey Imaging System (LI-COR). Protein bands were visualized by Image Studio Software (LI-COR). Fluorescence images were captured using an Olympus (Shinjuku, Tokyo, Japan) IX8 microscope and images were processed using SlideBook 5.0 software (3i, Denver, CO, USA).

\section{Results}

\subsection{Deguelin Treatment Inhibits HCMV Lytic Replication}

To identify novel FDA- or internationally-approved drugs that possess off-label antiviral activity against HCMV, we analyzed viral replication in fibroblasts treated with compounds from the commercially available Spectrum library (MicroSource Discovery Systems, Inc., Gaylordsville, CT, USA). We pretreated NuFF-1 cells with $50 \mu \mathrm{M}$ of each compound for 2 hours (h), after which we infected these cells with TB40/EmCherry-UL99eGFP (UL99eGFP) for $72 \mathrm{~h}$ at a multiplicity of 0.01 $\mathrm{TCID}_{50} / \mathrm{mL}$. Within this virus, eGFP is fused in frame to the UL99 ORF, which encodes pp28, a protein that functions during HCMV assembly. Expression of the UL99eGFP fusion is controlled by the virus' endogenous UL99 promoter, thus providing an easily identifiable late kinetic fluorescent marker to monitor viral replication in the compound library screen assay. We also included ganciclovir treatment, since it is a well-established HCMV anti-viral and thus served as an internal control for the screen. We prioritized compounds whose treatment resulted in a significant reduction in pp28, as measured by eGFP (Supplemental Table 1). One of the compounds that caused effective inhibition of pp28 fusion protein expression was deguelin (Spectrum). Thus, we focused our efforts to understanding the impact of deguelin on HCMV replication. First, we confirmed the above finding by pre-treating NuFF-1 cells with either vehicle (DMSO) or deguelin $(250 \mathrm{nM})$ for $1 \mathrm{~h}$ prior to infection with UL99eGFP $(\mathrm{moi}=1.0)$. At $72 \mathrm{hpi}$, we visualized each infected cell population by immunoflourescence and confirmed that deguelin treatment significantly reduced the expression of the viral late protein encoded by UL99, pp28, fused in-frame to eGFP, whose expression occurs only after efficient viral DNA replication (Figure 1) similar to the published subcellular localization of untagged UL99 [20]. 


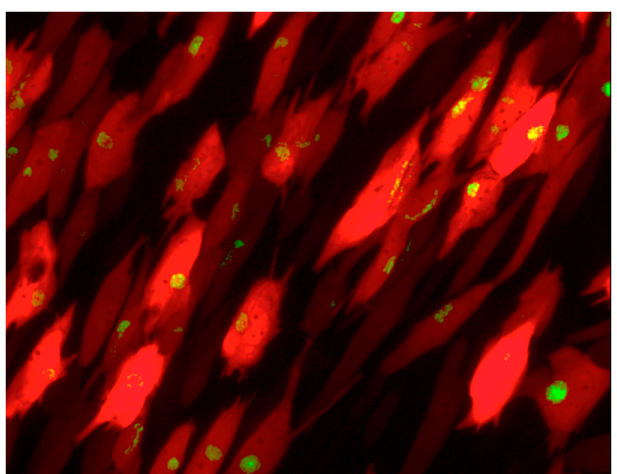

(a) Vehicle

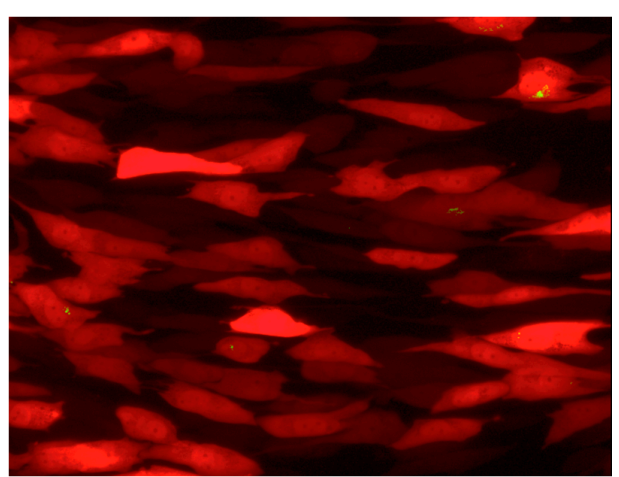

(b) Deguelin (250 nM)

Figure 1. Deguelin significantly reduces the expression of late gene products in HCMV-infected NuFF-1 cells. NuFF-1 cells were infected with TB40/EmCherry-UL99eGFP (UL99eGFP; moi = 1.0) in the presence of (a) vehicle (DMSO) or (b) deguelin ( $250 \mathrm{nM})$ for $72 \mathrm{~h}$. Red, mCherry (marker of infection); green, eGFP (pp28 expression).

Herpesvirus lytic replication is a highly coordinated phase of infection, during which viral genes are expressed in a synchronized cascade. Immediate early (IE) genes are transcribed first, whose proteins are involved in immune evasion and facilitate the expression of early (E) genes. E proteins facilitate viral DNA replication, which once completed, triggers the expression of L genes and their proteins, which encode virion components and facilitate viral egress. If any of these stages are impeded, the following step in the cascade is also impacted. Since we observed deguelin treatment inhibited pp28 expression, we next asked if viral DNA replication is impacted by deguelin and at what concentration. To this end, we pretreated NuFF-1 cells for $1 \mathrm{~h}$ with deguelin at varying concentrations and then infected these cells with UL99eGFP at a high (moi $=1.0 ; 7 \mathrm{~d})$ or low (moi $=0.01 ; 14 \mathrm{~d}$ ) multiplicity. At each respective time point, we assessed the cell-associated viral DNA by qPCR for the viral genome, and then calculated the deguelin concentration at which viral DNA is reduced by half $\left(\mathrm{IC}_{50}\right)$. Our results show that deguelin treatment significantly reduces HCMV cell-associated viral DNA at both multiplicities tested. We found that for the high moi, the $\mathrm{IC}_{50}$ concentration for deguelin was $55.8 \mathrm{nM}$, whereas the deguelin $\mathrm{IC}_{50}$ value for the low moi infection was $23.4 \mathrm{nM}$ (Figure 2a,b). We anticipated a lower $\mathrm{IC}_{50}$ value for the low moi infection, as such growth curves required subsequent rounds of viral replication and infection.

We reasoned that this significant reduction in cell-associated viral DNA would result in a significant impact on the production of the infectious virus. Hence, to determine the impact of deguelin on the release of extracellular, infectious virions, we pre-treated NuFF-1 cells with vehicle (DMSO) or varying concentrations of deguelin for $1 \mathrm{~h}$, and then infected these cells with UL99eGFP $(\mathrm{moi}=1.0)$ for $7 \mathrm{~d}$. We then harvested the cell-free supernatant and determined the titer of virus released by $\mathrm{TCID}_{50}$ on naïve NuFF-1 cells. We found that as little as $72 \mathrm{nM}$ was sufficient to inhibit infectious virion production by half (Figure 2c). If the compound adversely impacts the health of the host cell irrespective of viral infection, we would expect to observe a reduction in viral replication following drug treatment, thereby leading to a false-positive result when measuring the antiviral response. Thus, to determine the toxicity of deguelin on NuFF-1 cells in the absence of HCMV infection, we monitored cell viability by quantifying cellular metabolic activity as well as cell doubling times after treatment with deguelin in various concentrations. Importantly, we found that deguelin treatment was neither cytotoxic nor cytostatic to NuFF-1 cells at concentrations found to be inhibitory to HCMV replication (Figure 3a,b). Taken together, our in vitro findings show that deguelin inhibits HCMV lytic replication at concentrations that display little-to-no adverse effect on cell viability. 


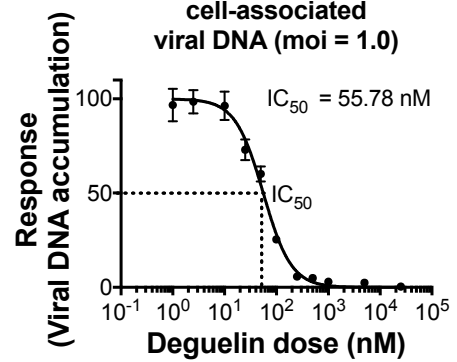

(a)

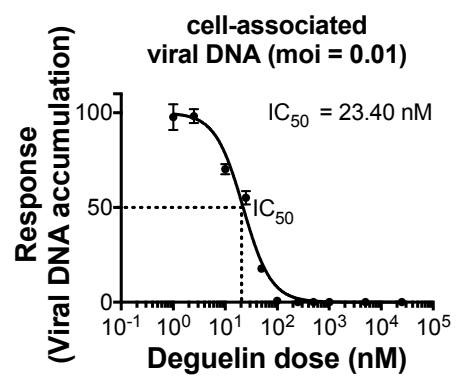

(b)

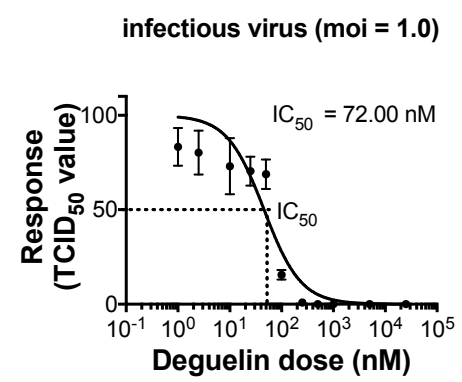

(c)

Figure 2. Deguelin suppresses HCMV replication in infected fibroblasts. NuFF-1 cells were infected with UL99eGFP in the presence of vehicle (DMSO) or deguelin at either (a) a high multiplicity (moi = 1.0) for $7 \mathrm{~d}$, or $(\mathbf{b})$ a low multiplicity (moi $=0.01$ ) for $14 \mathrm{~d}$. Cell-associated DNA was harvested from the respective cultures and analyzed by qPCR using primers directed at UL122. Samples were analyzed in triplicate and normalized to cellular MDM2. (c) NuFF-1 cells were infected as in (a), and at 7 dpi, the cell-free virus was harvested and viral titers were analyzed by TCID $\mathrm{ID}_{50}$. For all panels, error bars represent the standard deviation of three technical replicates. Replicate assays were performed $(n=3)$, and a representative biological replicate is shown in each panel.

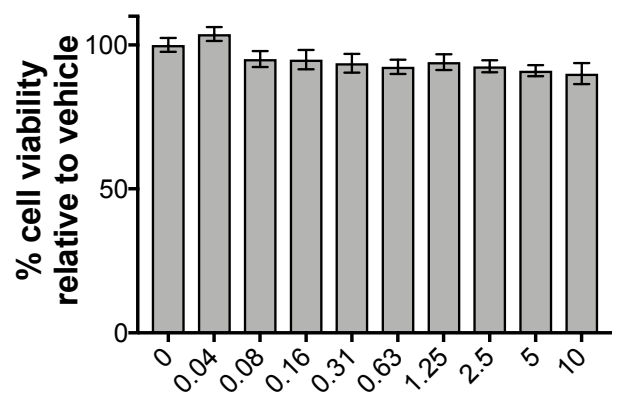

Deguelin concentration $(\mu \mathrm{M})$

(a)

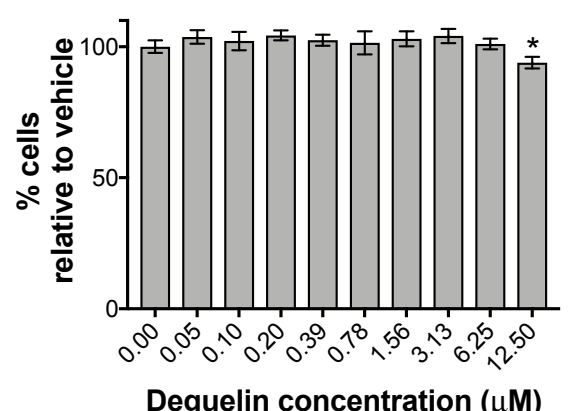

(b)

Figure 3. Deguelin treatment was not cytotoxic or cytostatic to fibroblasts. (a) NuFF-1 cells were grown to confluence and then treated with vehicle (DMSO) or increasing concentrations of deguelin, as indicated, for $72 \mathrm{~h}$. Cell viability was then assessed by 3-(4,5-dimethylthiazol-2-yl)-2,5-diphenyltetrazolium bromide (MTT) assay. Data was recorded at $570 \mathrm{~nm}$ using a Cytation 3 plate reader. Data is presented as percent (\%) inhibition relative to vehicle. (b) NuFF-1 cells were plated at $25 \%$ confluence and then treated with vehicle (DMSO) or increasing concentrations of deguelin. Cells were allowed to undergo two cell doublings, and were then assayed using the method used in (a). Data is presented as the number of cells relative to vehicle. Error bars represent the standard deviation of three technical replicates. Replicate assays were performed $(n=3)$, and a representative biological replicate is shown in each panel. Statistical analyses were performed using Student's $t$-test between each indicated concentration relative to the vehicle-treated cells; ${ }^{*} p<0.01$.

\subsection{Deguelin Treatment Effectively Inhibits Ganciclovir-Resistant HCMV}

Nucleoside analogues are the standard of care treatment administered to patients undergoing HCMV reactivation, the most common of which is ganciclovir. However, some strains of HCMV are resistant to this anti-viral, rendering these patients refractive to this treatment. Ganciclovir resistance is attributed to mutations within the HCMV-encoded kinase, UL97, underscoring the need for novel therapies to suppress HCMV lytic replication. The reported effects of deguelin on cancer cells are mediated through host cell protein targeting and thus we predict that it does not require kinase phosphorylation to function. Therefore, we hypothesized that a ganciclovir-resistant HCMV strain would be sensitive to this drug. To determine the effectiveness of deguelin on inhibiting ganciclovir-resistant HCMV, we utilized TReGFP. This BAC-derived strain lacks codons 591-594 of 
UL97, rendering it less responsive to ganciclovir treatment [21]. First, we pretreated NuFF-1 cells with the well-established effective dose of ganciclovir $(10 \mu \mathrm{M})$ for $1 \mathrm{~h}$. We then infected these cultures with either UL99eGFP (a TB40/E-derived recombinant) or TReGFP for $7 \mathrm{~d}$ (moi = 1.0). We then measured viral DNA replication by quantifying viral genomes using qPCR. We confirmed that TReGFP was less responsive to this treatment compared to UL99eGFP (Figure 4a). While, ganciclovir did inhibit TReGFP by approximately 50 percent, UL99eGFP displayed almost 97\% inhibition following ganciclovir treatment. However, when we repeated this experiment using deguelin, we found that viral DNA replication from both UL99eGFP and TReGFP were significantly inhibited following a 250 nM deguelin treatment by approximately $95 \%$ (Figure $4 \mathrm{~b}$ ). These data suggest that deguelin inhibits ganciclovir-resistant HCMV.

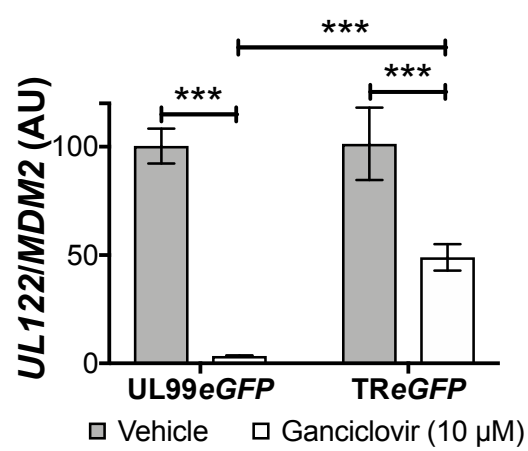

(a)

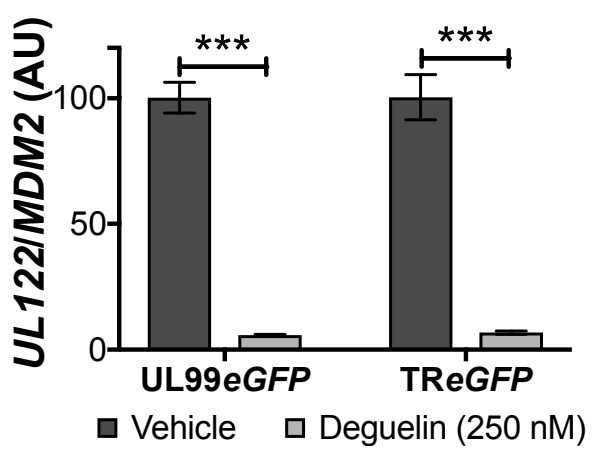

(b)

Figure 4. Ganciclovir-resistant HCMV is sensitive to deguelin treatment. NuFF-1 cells were treated with (a) ganciclovir $(10 \mu \mathrm{M})$ or $(\mathbf{b})$ deguelin $(250 \mathrm{nM})$ for $1 \mathrm{~h}$, after which cultures were infected with either TB40/EmCherry-UL99eGFP (UL99eGFP) or TReGFP for $7 \mathrm{~d}(\mathrm{moi}=1.0)$. Vehicle-treated cells in each case received DMSO. Cell-associated viral DNA was assessed by qPCR using primers directed at UL122. Each sample was analyzed in triplicate and normalized to cellular MDM2. Data is presented as the ratio of $U L 122 / M D M 2$ relative to vehicle. Error bars represent the standard deviation of three technical replicates. Replicate assays were performed $(n=3)$, and a representative biological replicate is shown in each panel. AU = arbitrary units. Statistical significance was calculated by two-way ANOVA, *** $p<0.0001$.

\subsection{Lytic Gene Transcription Is Inhibited by Deguelin Treatment}

Our data reveal that deguelin treatment impacts L viral protein expression (Figure 1) and viral DNA replication is significantly decreased in the presence of deguelin (Figure 2a,b). Our findings also indicate that deguelin treatment blocks the production of infectious virions (Figure 2c). To begin to understand the point during viral lytic replication at which deguelin functions, we pre-treated NuFF-1 cells with vehicle (DMSO) or deguelin (250 nM) and then infected these cells with UL99eGFP (moi $=1.0$ ). We collected total RNA at the indicated time points and assessed two representative genes from each class of lytic gene transcription: UL123 and UL122 (IE), UL44 and UL54 (E), and UL32 and UL99 (L). We found that IE transcription was unaffected over the first $12 \mathrm{hpi}$ in response to deguelin treatment (Figure 5a,b), though we noted a minor yet statistically significant difference by $24 \mathrm{hpi}$. However, we found that deguelin significantly impacted each $\mathrm{E}$ and L viral transcript we tested by 4 dpi (Figure 5). These data suggest that deguelin impacts IE gene transcription at times consistent with the transition to $\mathrm{E}$ and $\mathrm{L}$ transcription and the drug treatment impact on $\mathrm{E}$ and $\mathrm{L}$ viral gene transcription is more pronounced. 
(a)

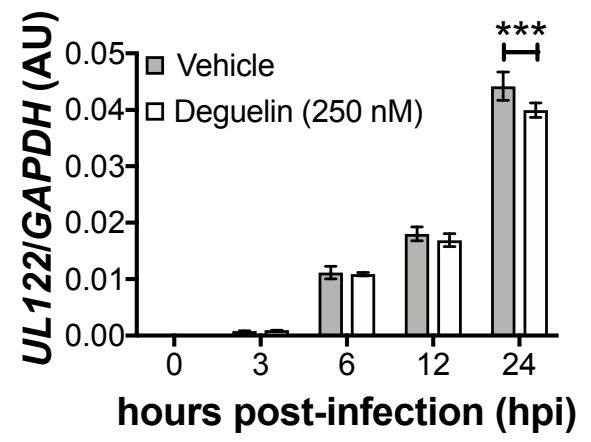

(c)

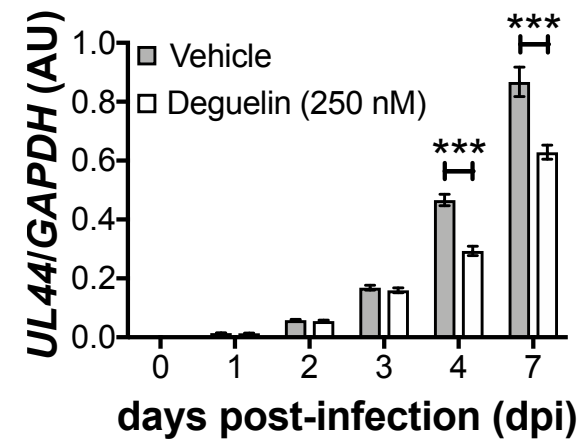

(e)

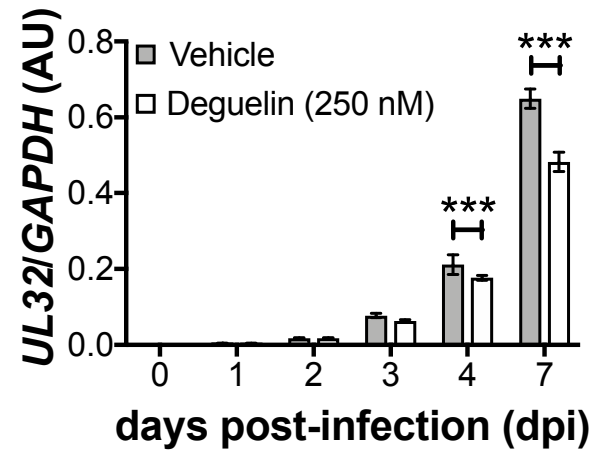

(b)

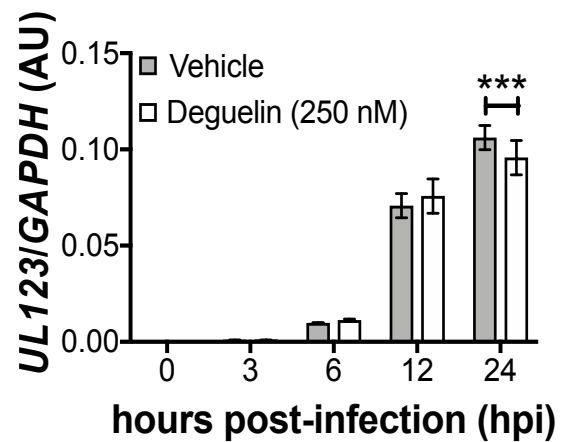

(d)

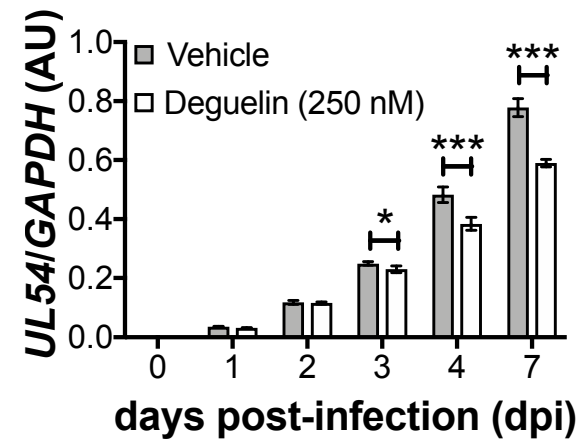

(f)

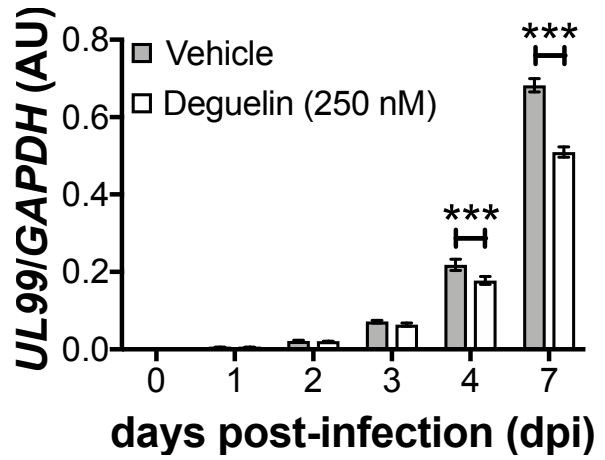

Figure 5. Treatment of HCMV infected fibroblasts with deguelin decreases IE, E, and L gene transcripts. NuFF-1 cells were treated with vehicle (DMSO) or deguelin (250 nM) for $1 \mathrm{~h}$, after which cultures were infected with UL99eGFP (moi = 1.0). Total RNA was collected at the indicated time points. Viral transcripts were assessed by RTqPCR using the following primers: (a) UL123 and (b) UL122 (IE); (c) UL44 and (d) UL54 (E); (e) UL32 and (f) UL99 (L). Each sample was analyzed in triplicate and normalized to cellular GAPDH. Error bars represent the standard deviation of three technical replicates. Replicate assays were performed $(n=3)$, and a representative biological replicate is shown in each panel. AU $=$ arbitrary units. Statistical significance was calculated by two-way ANOVA, ${ }^{*} p<0.05$, ** $p<0.005,{ }^{* * *} p<0.0001$.

\subsection{Deguelin Inhibits Viral Early Protein Expression}

To further dissect the stage of lytic replication impacted by deguelin treatment, we next asked if viral protein expression was impacted. We treated NuFF-1 cells with either vehicle (DMSO) or deguelin $(250 \mathrm{nM})$ for $1 \mathrm{~h}$ and then infected these cells with UL99eGFP (moi = 1.0). We collected total protein lysates over a time course of $4 \mathrm{~d}$ and assessed a representative viral protein from each of the kinetic classes of viral proteins. Consistent with our RNA data (Figure 5), we found that E (pUL44) and L (pp28) protein expression was significantly decreased in the deguelin-treated cells compared to those treated with vehicle. Additionally, we found that IE2-86, an IE protein, exhibited slightly delayed expression in the deguelin-treated cells that eventually accumulated to the levels seen in the vehicle control treated infections. However, IE2-60, an IE2 protein isoform that accumulates at late times of 
infection, displayed a significant reduction in protein expression in deguelin-treated cells compared to those that received vehicle treatment (Figure 6). Taken together, these data suggest that deguelin impacts HCMV lytic replication at times consistent with E gene/protein production.
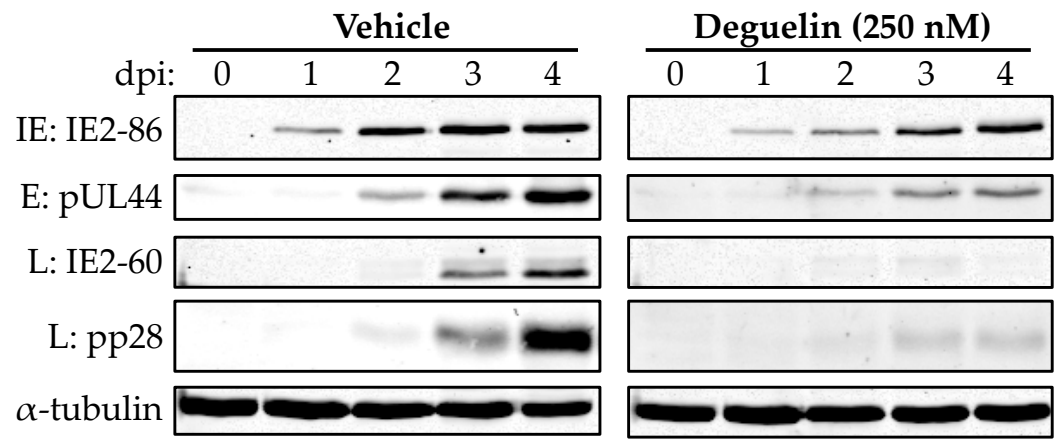

Figure 6. Deguelin treatment results in a reduction of E protein translation in HCMV infected fibroblasts. NuFF-1 cells were treated with vehicle (DMSO) or deguelin (250 nM) for $1 \mathrm{~h}$, after which cultures were infected with UL99eGFP ( $\mathrm{moi}=1.0$ ). Total cell lysates were collected over $4 \mathrm{~d}$ and viral protein expression was assessed by immunoblot for the following proteins: IE2-86 (IE), pUL44 (E), pp28 (L), and IE2-60 (L). Tubulin is shown as a loading control. Data is from a representative experiment $(n=3)$.

\section{Discussion}

In the current study, we have shown that the naturally-occurring rotenoid deguelin significantly inhibits HCMV lytic replication. Specifically, our results indicate that sub-micromolar levels of deguelin impacts HCMV lytic replication as early as viral E transcript and protein expression. In turn, viral DNA, viral L gene and protein expression, and the production of infectious virus are all significantly decreased compared to infected fibroblasts that were treated only with vehicle. Importantly, HCMV strains that are resistant to ganciclovir treatment remain sensitive to deguelin treatment. Collectively, our data reveal a potentially new therapy to inhibit HCMV lytic replication.

Deguelin has been studied for just over 20 years, and much of the work has focused on its potential use as an anti-cancer agent. More specifically, investigators have found deguelin displays anti-cancer activities both in vitro and in vivo for a variety of cancers across tissue types, including non-small cell lung cancer [22-25], triple negative breast cancer [26,27], prostate cancer [28], gastric cancer [29-31], hepatocellular carcinoma [32,33], esophageal squamous cell carcinoma [34,35], acute myeloid leukemia [36-39], pancreatic cancer [40-42], head and neck squamous cell carcinoma [43-45], lung squamous cell carcinoma [46], and androgen receptor-positive breast cancer [47]. Deguelin induces apoptosis in non-small cell lung cancer cells, for example, by repressing Noxa through B lymphoma Mo-MLV insertion region 1 homolog (BMI1) regulation [25]. This compound also down-regulates hexokinase II-mediated glycolysis in these cancer cells [23], suggesting that deguelin functions are multifaceted. Deguelin also targets multiple signaling pathways, including Wingless-related integration site (Wnt) / $\beta$-catenin, nuclear factor kappa-light-chain-enhancer of activated B cells (NFkB), and PI3K/Akt, all of which are pro-survival pathways. Coupled with its ability to induce pro-apoptotic factors, deguelin clearly inhibits both cell survival and cell proliferation. In the case of lung squamous cell carcinoma cells, deguelin induces apoptosis via regulating galectin-1 expression [46]. In other settings, such as hepatocellular carcinoma cells, deguelin attenuates hepatocyte growth factor (HGF)-mediated HGF receptor (a.k.a. c-Met) activation, leading to vascular endothelial growth factor (VEGF) suppression, thereby suppressing angiogenesis and reducing pro-angiogenic factors in these cells [33]. In line with this observation, several groups have reported that deguelin inhibits hypoxia inducible factor- $1 \alpha(\mathrm{HIF}-1 \alpha)$ [48], a cellular protein overexpressed in many cancers. HIF- $1 \alpha$ promotes tumor growth and metastases by promoting angiogenesis and regulating host cell metabolism. Like its function in regulating apoptosis, deguelin uses multiple mechanisms to inhibit angiogenesis. 
The ability of this compound to target multiple pathways involved in the progression of cancer has made deguelin an attractive, novel anti-cancer treatment.

As discussed above, deguelin inhibits a variety of signaling pathways that ultimately lead to the inhibition of cell survival and proliferation. Interestingly, many viruses, including HCMV, require many of these same factors that deguelin inhibits. For example, HCMV activates both the PI3K and mammalian target of rapamycin (mTOR) complex 1 (mTORC1) pathways [49], both of which are inhibited by deguelin $[45,47,50]$. In line with these data, HCMV stimulates survivin by inducing IL-6 [51], while deguelin inhibits survivin [12], a downstream target of the mTOR signaling [52]. During lytic replication, HCMV activates NFKB signaling, via upregulation of IкB kinases (IKKs), and in fact activation of this pathway is critical for activating the HCMV major immediate early promoter (MIEP) [53]. Deguelin, however, inhibits NFKB signaling and its downstream regulated genes by suppressing IKKs [54]. Similarly, as mentioned above, deguelin inhibits VEGF [33,48], HIF-1 $\alpha$ [48], and Wnt/ $\beta$-catenin [55], all of which HCMV activates during lytic replication [56-60]. Since deguelin inhibits many of the same pathways HCMV activates, it is attractive to speculate that the underlying mechanism of deguelin inhibition of HCMV lytic replication is multifaceted. Targeting cellular factors rather than those that are viral is a benefit, as most anti-viral compounds are directed against a specific viral protein. This is in contrast to anti-cancer therapies, which are directed against a host protein or pathway. Host-directed targeting as an antiviral therapeutic is attractive, as it limits viral resistance accumulation and has the capacity to target a wide range of viruses from distinct families. We propose that deguelin possesses antiviral characteristics and may serve as a suitable substrate for the development of novel antiviral compounds with pharmacological properties suitable for drug development.

\section{Conclusions}

In summary, the naturally occurring rotenoid, deguelin, significantly inhibits HCMV lytic replication. Importantly, we have shown that deguelin is effective at inhibiting ganciclovir-resistant HCMV, and thus may prove a suitable alternative therapeutic to treat multi-drug resistant HCMV.

Author Contributions: Conceptualization of the experimental design, M.N., C.M.O., and E.A.M.; investigation, M.N., C.M.O., and E.A.M.; writing—original draft preparation, C.M.O.; writing-review and editing, M.N., C.M.O., and E.A.M.; supervision, C.M.O. and E.A.M.; funding acquisition, E.A.M.

Funding: This research was funded by NIH NIAID, grant\# R01AI101080 to E.A.M.

Acknowledgments: The authors would like to thank Melanie Hoffner and Earl Poptic (Cleveland Clinic Molecular Screening Core) for their assistance with the compound libraries. The authors would also like to thank Fadi Najm (Genetics and Genome Sciences Department, Case Western Reserve University School of Medicine) for assistance with the Operetta High Content Imaging System.

Conflicts of Interest: The authors declare no conflict of interest.

\section{References}

1. Poole, C.L.; James, S.H. Antiviral therapies for herpesviruses: Current agents and new directions. Clin. Ther. 2018, 40, 1282-1298. [CrossRef] [PubMed]

2. Littler, E.; Stuart, A.D.; Chee, M.S. Human cytomegalovirus UL97 open reading frame encodes a protein that phosphorylates the antiviral nucleoside analogue ganciclovir. Nature 1992, 358, 160-162. [CrossRef] [PubMed]

3. Jung, D.; Dorr, A. Single-dose pharmacokinetics of valganciclovir in HIV- and CMV-seropositive subjects. J. Clin. Pharmacol. 1999, 39, 800-804. [CrossRef] [PubMed]

4. Biron, K.K.; Harvey, R.J.; Chamberlain, S.C.; Good, S.S.; Smith, A.A., 3rd; Davis, M.G.; Talarico, C.L.; Miller, W.H.; Ferris, R.; Dornsife, R.E.; et al. Potent and selective inhibition of human cytomegalovirus replication by 1263w94, a benzimidazole l-riboside with a unique mode of action. Antimicrob. Agents Chemother. 2002, 46, 2365-2372. [CrossRef] [PubMed] 
5. Ringden, O.; Wilczek, H.; Lonnqvist, B.; Gahrton, G.; Wahren, B.; Lernestedt, J.O. Foscarnet for cytomegalovirus infections. Lancet 1985, 1, 1503-1504. [CrossRef]

6. $\quad$ Lalezari, J.P.; Drew, W.L.; Glutzer, E.; James, C.; Miner, D.; Flaherty, J.; Fisher, P.E.; Cundy, K.; Hannigan, J.; Martin, J.C.; et al. (S)-1-[3-hydroxy-2-(phosphonylmethoxy)propyl]cytosine (cidofovir): Results of a phase i/ii study of a novel antiviral nucleotide analogue. J. Infect. Dis. 1995, 171, 788-796. [CrossRef] [PubMed]

7. Jacobsen, T.; Sifontis, N. Drug interactions and toxicities associated with the antiviral management of cytomegalovirus infection. Am. J. Health Syst. Pharm. 2010, 67, 1417-1425. [CrossRef] [PubMed]

8. Bonatti, H.; Sifri, C.D.; Larcher, C.; Schneeberger, S.; Kotton, C.; Geltner, C. Use of cidofovir for cytomegalovirus disease refractory to ganciclovir in solid organ recipients. Surg. Infect. 2017, 18, 128-136. [CrossRef] [PubMed]

9. Marty, F.M.; Ljungman, P.; Chemaly, R.F.; Maertens, J.; Dadwal, S.S.; Duarte, R.F.; Haider, S.; Ullmann, A.J.; Katayama, Y.; Brown, J.; et al. Letermovir prophylaxis for cytomegalovirus in hematopoietic-cell transplantation. N. Engl. J. Med. 2017, 377, 2433-2444. [CrossRef] [PubMed]

10. Chou, S. A third component of the human cytomegalovirus terminase complex is involved in letermovir resistance. Antiviral Res. 2017, 148, 1-4. [CrossRef] [PubMed]

11. Chou, S.; Satterwhite, L.E.; Ercolani, R.J. New locus of drug resistance in the human cytomegalovirus UL56 gene revealed by in vitro exposure to letermovir and ganciclovir. Antimicrob. Agents Chemother. 2018, 62. [CrossRef] [PubMed]

12. Wang, Y.; Ma, W.; Zheng, W. Deguelin, a novel anti-tumorigenic agent targeting apoptosis, cell cycle arrest and anti-angiogenesis for cancer chemoprevention. Mol. Clin. Oncol. 2013, 1, 215-219. [CrossRef] [PubMed]

13. O'Connor, C.M.; Shenk, T. Human cytomegalovirus pus27 g protein-coupled receptor homologue is required for efficient spread by the extracellular route but not for direct cell-to-cell spread. J. Virol. 2011, 85, 3700-3707. [CrossRef] [PubMed]

14. Murphy, E.; Yu, D.; Grimwood, J.; Schmutz, J.; Dickson, M.; Jarvis, M.A.; Hahn, G.; Nelson, J.A.; Myers, R.M.; Shenk, T.E. Coding potential of laboratory and clinical strains of human cytomegalovirus. Proc. Natl. Acad. Sci. USA 2003, 100, 14976-14981. [CrossRef] [PubMed]

15. O'Connor, C.M.; Nukui, M.; Gurova, K.V.; Murphy, E.A. Inhibition of the fact complex reduces transcription from the human cytomegalovirus major immediate early promoter in models of lytic and latent replication. J. Virol. 2016, 90, 4249-4253. [CrossRef] [PubMed]

16. Murphy, E.; Vanicek, J.; Robins, H.; Shenk, T.; Levine, A.J. Suppression of immediate-early viral gene expression by herpesvirus-coded micrornas: Implications for latency. Proc. Natl. Acad. Sci. USA 2008, 105, 5453-5458. [CrossRef] [PubMed]

17. Warming, S.; Costantino, N.; Court, D.L.; Jenkins, N.A.; Copeland, N.G. Simple and highly efficient BAC recombineering using galk selection. Nucleic Acids Res. 2005, 33, e36. [CrossRef] [PubMed]

18. Terhune, S.; Torigoi, E.; Moorman, N.; Silva, M.; Qian, Z.; Shenk, T.; Yu, D. Human cytomegalovirus ul38 protein blocks apoptosis. J. Virol. 2007, 81, 3109-3123. [CrossRef] [PubMed]

19. Nevels, M.; Paulus, C.; Shenk, T. Human cytomegalovirus immediate-early 1 protein facilitates viral replication by antagonizing histone deacetylation. Proc. Natl. Acad. Sci. USA 2004, 101, 17234-17239. [CrossRef] [PubMed]

20. Silva, M.C.; Yu, Q.C.; Enquist, L.; Shenk, T. Human cytomegalovirus UL99-encoded pp28 is required for the cytoplasmic envelopment of tegument-associated capsids. J. Virol. 2003, 77, 10594-10605. [CrossRef] [PubMed]

21. Smith, I.L.; Taskintuna, I.; Rahhal, F.M.; Powell, H.C.; Ai, E.; Mueller, A.J.; Spector, S.A.; Freeman, W.R. Clinical failure of CMV retinitis with intravitreal cidofovir is associated with antiviral resistance. Arch. Ophthalmol. 1998, 116, 178-185. [CrossRef] [PubMed]

22. Ji, B.C.; Yu, C.C.; Yang, S.T.; Hsia, T.C.; Yang, J.S.; Lai, K.C.; Ko, Y.C.; Lin, J.J.; Lai, T.Y.; Chung, J.G. Induction of DNA damage by deguelin is mediated through reducing DNA repair genes in human non-small cell lung cancer NCI-h460 cells. Oncol. Rep. 2012, 27, 959-964. [CrossRef] [PubMed]

23. Li, W.; Gao, F.; Ma, X.; Wang, R.; Dong, X.; Wang, W. Deguelin inhibits non-small cell lung cancer via down-regulating hexokinases II-mediated glycolysis. Oncotarget 2017, 8, 32586-32599. [CrossRef] [PubMed]

24. Li, W.; Yu, X.; Ma, X.; Xie, L.; Xia, Z.; Liu, L.; Yu, X.; Wang, J.; Zhou, H.; Zhou, X.; et al. Deguelin attenuates non-small cell lung cancer cell metastasis through inhibiting the ctsz/fak signaling pathway. Cell. Signal. 2018, 50, 131-141. [CrossRef] [PubMed] 
25. Li, W.; Yu, X.; Xia, Z.; Yu, X.; Xie, L.; Ma, X.; Zhou, H.; Liu, L.; Wang, J.; Yang, Y.; et al. Repression of noxa by BMI1 contributes to deguelin-induced apoptosis in non-small cell lung cancer cells. J. Cell. Mol. Med. 2018. [CrossRef] [PubMed]

26. Mehta, R.; Katta, H.; Alimirah, F.; Patel, R.; Murillo, G.; Peng, X.; Muzzio, M.; Mehta, R.G. Deguelin action involves C-MET and EGFR signaling pathways in triple negative breast cancer cells. PLOS ONE 2013, 8, e65113. [CrossRef] [PubMed]

27. Suh, Y.A.; Kim, J.H.; Sung, M.A.; Boo, H.J.; Yun, H.J.; Lee, S.H.; Lee, H.J.; Min, H.Y.; Suh, Y.G.; Kim, K.W.; et al. A novel antitumor activity of deguelin targeting the insulin-like growth factor (IGF) receptor pathway via up-regulation of IGF-binding protein-3 expression in breast cancer. Cancer Lett. 2013, 332, 102-109. [CrossRef] [PubMed]

28. Thamilselvan, V.; Menon, M.; Thamilselvan, S. Anticancer efficacy of deguelin in human prostate cancer cells targeting glycogen synthase kinase-3 beta/beta-catenin pathway. Int. J. Cancer 2011, 129, 2916-2927. [CrossRef] [PubMed]

29. Kang, W.; Zheng, X.; Wang, P.; Guo, S. Deguelin exerts anticancer activity of human gastric cancer MGC-803 and MKN-45 cells in vitro. Int. J. Mol. Med. 2018, 41, 3157-3166. [CrossRef] [PubMed]

30. Lee, H.; Lee, J.H.; Jung, K.H.; Hong, S.S. Deguelin promotes apoptosis and inhibits angiogenesis of gastric cancer. Oncol. Rep. 2010, 24, 957-963. [PubMed]

31. Li, Z.; Wu, C.; Wu, J.; Ji, M.; Shi, L.; Jiang, J.; Xu, B.; Yuan, J. Synergistic antitumor effects of combined deguelin and cisplatin treatment in gastric cancer cells. Oncol. Lett. 2014, 8, 1603-1607. [CrossRef] [PubMed]

32. Lee, J.H.; Lee, D.H.; Lee, H.S.; Choi, J.S.; Kim, K.W.; Hong, S.S. Deguelin inhibits human hepatocellular carcinoma by antiangiogenesis and apoptosis. Oncol. Rep. 2008, 20, 129-134. [CrossRef] [PubMed]

33. Li, M.; Yu, X.; Li, W.; Liu, T.; Deng, G.; Liu, W.; Liu, H.; Gao, F. Deguelin suppresses angiogenesis in human hepatocellular carcinoma by targeting HGF-C-MET pathway. Oncotarget 2018, 9, 152-166. [CrossRef] [PubMed]

34. Baba, Y.; Kato, Y. Deguelin, a novel anti-tumorigenic agent in human esophageal squamous cell carcinoma. EBioMedicine 2017, 26, 10. [CrossRef] [PubMed]

35. Yu, X.; Liang, Q.; Liu, W.; Zhou, L.; Li, W.; Liu, H. Deguelin, an aurora B kinase inhibitor, exhibits potent anti-tumor effect in human esophageal squamous cell carcinoma. EBioMedicine 2017, 26, 100-111. [CrossRef] [PubMed]

36. Bortul, R.; Tazzari, P.L.; Billi, A.M.; Tabellini, G.; Mantovani, I.; Cappellini, A.; Grafone, T.; Martinelli, G.; Conte, R.; Martelli, A.M. Deguelin, a PI3K/AKT inhibitor, enhances chemosensitivity of leukaemia cells with an active pi3k/akt pathway. Br. J. Haematol. 2005, 129, 677-686. [CrossRef] [PubMed]

37. Wang, Y.P.; Yi, S.; Wen, L.; Zhang, B.P.; Zhao, Z.; Hu, J.Y.; Zhao, F.; He, J.; Fang, J.; Zhang, C.; et al. Nontoxic-dose of deguelin induce NPMC + aml cell differentiation by selectively targeting MT NPM1/SIRT1 instead of HDAC1/3. Curr. Cancer Drug Targets 2014, 14, 685-699. [CrossRef] [PubMed]

38. Yi, S.; Wen, L.; He, J.; Wang, Y.; Zhao, F.; Zhao, J.; Zhao, Z.; Cui, G.; Chen, Y. Deguelin, a selective silencer of the NPM1 mutant, potentiates apoptosis and induces differentiation in aml cells carrying the npm1 mutation. Ann. Hematol. 2015, 94, 201-210. [CrossRef] [PubMed]

39. Zhang, X.; Zhao, Z.; Yi, S.; Wen, L.; He, J.; Hu, J.; Ruan, J.; Fang, J.; Chen, Y. Deguelin induced differentiation of mutated npm1 acute myeloid leukemia in vivo and in vitro. Anticancer Drugs 2017, 28, 723-738. [CrossRef] [PubMed]

40. Boreddy, S.R.; Srivastava, S.K. Deguelin suppresses pancreatic tumor growth and metastasis by inhibiting epithelial-to-mesenchymal transition in an orthotopic model. Oncogene 2013, 32, 3980-3991. [CrossRef] [PubMed]

41. Xu, X.D.; Zhao, Y.; Zhang, M.; He, R.Z.; Shi, X.H.; Guo, X.J.; Shi, C.J.; Peng, F.; Wang, M.; Shen, M.; et al. Inhibition of autophagy by deguelin sensitizes pancreatic cancer cells to doxorubicin. Int. J. Mol. Sci. 2017, 18, 370. [CrossRef] [PubMed]

42. Zheng, W.; Lu, S.; Cai, H.; Kang, M.; Qin, W.; Li, C.; Wu, Y. Deguelin inhibits proliferation and migration of human pancreatic cancer cells in vitro targeting hedgehog pathway. Oncol. Lett. 2016, 12, 2761-2765. [CrossRef] [PubMed]

43. Baba, Y.; Fujii, M.; Maeda, T.; Suzuki, A.; Yuzawa, S.; Kato, Y. Deguelin induces apoptosis by targeting both EGFR-AKT and IGF1R-AKT pathways in head and neck squamous cell cancer cell lines. Biomed. Res. Int. 2015, 2015, 657179. [CrossRef] [PubMed] 
44. Baba, Y.; Maeda, T.; Suzuki, A.; Takada, S.; Fujii, M.; Kato, Y. Deguelin potentiates apoptotic activity of an egfr tyrosine kinase inhibitor (AG1478) in PIK3CA-mutated head and neck squamous cell carcinoma. Int. J. Mol. Sci. 2017, 18, 262. [CrossRef] [PubMed]

45. Yang, Y.L.; Ji, C.; Bi, Z.G.; Lu, C.C.; Wang, R.; Gu, B.; Cheng, L. Deguelin induces both apoptosis and autophagy in cultured head and neck squamous cell carcinoma cells. PLoS ONE 2013, 8, e54736. [CrossRef] [PubMed]

46. Yan, B.; Zhao, D.; Yao, Y.; Bao, Z.; Lu, G.; Zhou, J. Deguelin induces the apoptosis of lung squamous cell carcinoma cells through regulating the expression of galectin-1. Int. J. Biol. Sci. 2016, 12, 850-860. [CrossRef] [PubMed]

47. Robles, A.J.; Cai, S.X.; Cichewicz, R.H.; Mooberry, S.L. Selective activity of deguelin identifies therapeutic targets for androgen receptor-positive breast cancer. Breast Cancer Res. Treat. 2016, 157, 475-488. [CrossRef] [PubMed]

48. Oh, S.H.; Woo, J.K.; Jin, Q.; Kang, H.J.; Jeong, J.W.; Kim, K.W.; Hong, W.K.; Lee, H.Y. Identification of novel antiangiogenic anticancer activities of deguelin targeting hypoxia-inducible factor-1 alpha. Int. J. Cancer 2008, 122, 5-14. [CrossRef] [PubMed]

49. Vincent, H.A.; Ziehr, B.; Moorman, N.J. Human cytomegalovirus strategies to maintain and promote mRNA translation. Viruses 2016, 8, 97. [CrossRef] [PubMed]

50. Chun, K.H.; Kosmeder, J.W., 2nd; Sun, S.; Pezzuto, J.M.; Lotan, R.; Hong, W.K.; Lee, H.Y. Effects of deguelin on the phosphatidylinositol 3-kinase/AKT pathway and apoptosis in premalignant human bronchial epithelial cells. J. Natl. Cancer Inst. 2003, 95, 291-302. [CrossRef] [PubMed]

51. Botto, S.; Streblow, D.N.; DeFilippis, V.; White, L.; Kreklywich, C.N.; Smith, P.P.; Caposio, P. Il-6 in human cytomegalovirus secretome promotes angiogenesis and survival of endothelial cells through the stimulation of survivin. Blood 2011, 117, 352-361. [CrossRef] [PubMed]

52. Vaira, V.; Lee, C.W.; Goel, H.L.; Bosari, S.; Languino, L.R.; Altieri, D.C. Regulation of survivin expression by IGF-1/MTOR signaling. Oncogene 2007, 26, 2678-2684. [CrossRef] [PubMed]

53. DeMeritt, I.B.; Milford, L.E.; Yurochko, A.D. Activation of the NF-kb pathway in human cytomegalovirus-infected cells is necessary for efficient transactivation of the major immediate-early promoter. J. Virol. 2004, 78, 4498-4507. [CrossRef] [PubMed]

54. Nair, A.S.; Shishodia, S.; Ahn, K.S.; Kunnumakkara, A.B.; Sethi, G.; Aggarwal, B.B. Deguelin, an akt inhibitor, suppresses ikappabalpha kinase activation leading to suppression of NF-kb-regulated gene expression, potentiation of apoptosis, and inhibition of cellular invasion. J. Immunol. 2006, 177, 5612-5622. [CrossRef] [PubMed]

55. Murillo, G.; Peng, X.; Torres, K.E.; Mehta, R.G. Deguelin inhibits growth of breast cancer cells by modulating the expression of key members of the Wnt signaling pathway. Cancer Prev. Res. 2009, 2, 942-950. [CrossRef] [PubMed]

56. De Wit, R.H.; Mujic-Delic, A.; van Senten, J.R.; Fraile-Ramos, A.; Siderius, M.; Smit, M.J. Human cytomegalovirus encoded chemokine receptor us 28 activates the HIF- $1 \alpha /$ PKM2 axis in glioblastoma cells. Oncotarget 2016, 7, 67966-67985. [CrossRef] [PubMed]

57. Heiske, A.; Roettger, Y.; Bacher, M. Cytomegalovirus upregulates vascular endothelial growth factor and its second cellular kinase domain receptor in human fibroblasts. Viral Immunol. 2012, 25, 360-367. [CrossRef] [PubMed]

58. Langemeijer, E.V.; Slinger, E.; de Munnik, S.; Schreiber, A.; Maussang, D.; Vischer, H.; Verkaar, F.; Leurs, R.; Siderius, M.; Smit, M.J. Constitutive $\beta$-catenin signaling by the viral chemokine receptor US28. PLoS ONE 2012, 7, e48935. [CrossRef] [PubMed] 
59. Maussang, D.; Langemeijer, E.; Fitzsimons, C.P.; Stigter-van Walsum, M.; Dijkman, R.; Borg, M.K.; Slinger, E.; Schreiber, A.; Michel, D.; Tensen, C.P.; et al. The human cytomegalovirus-encoded chemokine receptor us28 promotes angiogenesis and tumor formation via cyclooxygenase-2. Cancer Res. 2009, 69, 2861-2869. [CrossRef] [PubMed]

60. Maussang, D.; Verzijl, D.; van Walsum, M.; Leurs, R.; Holl, J.; Pleskoff, O.; Michel, D.; van Dongen, G.A.; Smit, M.J. Human cytomegalovirus-encoded chemokine receptor us28 promotes tumorigenesis. Proc. Natl. Acad. Sci. USA 2006, 103, 13068-13073. [CrossRef] [PubMed]

(C) 2018 by the authors. Licensee MDPI, Basel, Switzerland. This article is an open access article distributed under the terms and conditions of the Creative Commons Attribution (CC BY) license (http:/ / creativecommons.org/licenses/by/4.0/). 